\title{
Cultural Tourism, Using A Multicriteria Analysis: Spanish World Heritage Cities
}

Juan-Antonio Mondéjar-Jiménez, Ph.D., University of Castilla-La Mancha, Spain María-Carmen García-Centeno, Ph.D., University San Pablo CEU, Spain Román Mínguez-Salido, Ph.D., University of Castilla-La Mancha, Spain José Mondéjar-Jiménez, Ph.D., University of Castilla-La Mancha, Spain María Cordente-Rodríguez, University of Castilla-La Mancha, Spain

\begin{abstract}
The city tourism has become a subject of growing interest in tourism research, in a dynamic sector and with a particularly complex behaviour. In this scenario, the management of available information turns out to be difficult. Until now, specialized literature in tourism has been focused on general analysis, but down to a higher level of disaggregation (cities), presents a greater complexity. This paper aims to classify cities declared World Heritage by UNESCO on the basis of information available, by applying a multicriteria decision aid method: The Promethee.
\end{abstract}

Keywords: tourism, World Heritage city, choice of destination, multicriteria decision.

\section{INTRODUCTION}

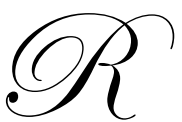

esearchers have shown in recent years a renewed interest in analyzing the tourism sector. The nature of tourism as a set of activities relating to housing, transportation, entertainment, promotion and marketing, among others, and the wide range of dimensions that converge in the product configuration justify their interpretation as a multifaceted fact (Mondéjar, Vargas, Mondéjar and Lorenzo, 2007). Thus, its study is approached from different disciplinary fields that try to analyze tourism with different methodologies and tools and taking into account their own epistemological foundations (Vera and Ivars, 2001). Furthermore, in recent years have proliferated papers published in this field using all levels of disaggregation: regional, national and international (eg, Daniel and Ramos, 2002, Ledesma and Navarro, 2000; Lim, 1997 ; Mondéjar, Mínguez, Meseguer and Garcia, 2010; Mondéjar, Vargas, Mondéjar and Gázquez, 2008, Otero, 1999; Sorensen, 2003 and Zou and Yang, 2004).

The growth level experienced by cultural tourism in recent years has been primarily motivated by a threefold cause: the increasing value of culture and heritage in the society, the tendency to abandon the traditional model of sun and sand and the growing importance of tertiary sector in the economy (Bedate, Sanz and Herrero, 2001). This binomial heritage-tourism has triggered a growth that has been most noticeable in the cities or historic areas declared "World Heritage" by UNESCO. These places are becoming established reference landmarks tourism, both cultural and mass, and in the context of urban tourism growth and new temporalities, where they have a promising future (Navia, 2009, Troitiño, 2000).

Tourism demand is changing at the same time as the rest of leisure motivations, and cultural tourism is considered as a higher level than mass tourism, consumerism and escapism. This requires a better knowledge of demand and a focus on customer, to satisfy an increasingly demanding tourist, along with proposals based on segmentation and specialization (Molina, Martín-Consuegra, Esteban and Díaz 2007). As a consequence, it is evident the need to configure the cultural tourism supply in terms of resources and infrastructures available at the destinations (Almeida, 2007; Esteban, Mondéjar, Mondéjar and Meseguer, 2009; García, 2007).

The decision to visit a particular tourist destination is determined by their motivations. As a matter of fact, an important part of the literature acknowledges that many tourists are more highly motivated to participate in 
cultural tourism than others. Moreover, they have been identified some models in the tourists visiting historical sites, discovering different behaviors and patterns, and even significant differences were detected between them (Gómez, Mondéjar and Sevilla, 2005; Mondéjar and Gómez, 2009). Nevertheless, only in a few occasions it has been carried out a classification of destinations based on their resources and this is, precisely, the aim of this work through the use of multicriteria decision techniques.

\section{METHODOLOGY}

PROMETHEE $^{1}$ method, proposed by Brans, Mareschal and Vincke (1984) and further developed among others by Brans and Vincke (1985), Goumans and Lygerou (2000), is a multicriteria decision aid method based on relations of improvement. There are numerous precedents for the application of multicriteria methods in the field of tourism in general (Blancas, Guerrero, and Lozano, 2009; Franco, Osorio, Nava and Regil, 2009; Montis and Nijkamp, 2006) and, particularly, for quality and specific destinations (Rozman, Potocnik, Pazek, Borec, Majkovic, and Bohanec, 2009; Brandis, Martín, Calle, Río, Troitiño, Gutiérrez and Lobo, 1998; Pérez, Camargo, Caballero and González, 2008).

To apply this method you must have a pay-off matrix. This pay-off matrix summarizes all the key elements that are part of the decision problem. These elements can include the following:

1- $\quad$ Alternatives. These are the various elements among which the decision maker has to choose or establish a preference order which is usually from the best to the worst alternative. In our case the alternatives to be considered will be eleven of the thirteen World Heritage cities of Spain: Ávila, Cáceres, Córdoba, Cuenca, Ibiza, Mérida, Salamanca, Santiago de Compostela, Segovia, Tarragona and Toledo. To make this selection the main source of information used has been the Group Heritage Cities (Troitiño, et. al, 2009).

2- $\quad$ Criteria. They are the different functions to be used to evaluate the alternatives. These criteria, depending on its character, can be maximized or minimized. In this paper we will use the next seventeen criteria: The interest attractions, places available to be visited, commercial index, tourism index, restaurants index, an index of economic activity, index of infrastructures, places available in four and five star hotels weighted for overnight stays, places available in hotels with three, two and one stars, all of them weighted by the overnight stays, percentage of overnights, hotel occupancy rate, average stay, number of consultations made in tourist offices, the whole capacity and budget for tourism. All these criteria will be maximized.

3- $\quad$ Evaluations which are the results obtained when each of the alternatives is evaluated under each criterion.

4- The weights measure the relative importance that the decision maker assigns to each of the criteria. Thus, the greater the weight the greater the relative importance of criteria and, conversely, the lower the weight the less importance of the criterion. These weights can be non-standardized or can be standardized previously to the analysis. To perform a robust analysis of the results quite often some scenarios are proposed using different criteria for calculating the weights. In our case we propose two different scenarios: one in which all criteria have equal weight and other in which the weights are calculated based on an objective entropy method for assigning weights according to the results of the decision matrix.

5- Generalized criteria that are functions of preference under which each criterion is evaluated. These generalized criteria are very important because they allow to establish the degree of preference between two alternatives when they are evaluated for each criterion. To facilitate the association between the alternative preferences for each criterion there have been proposed in the literature the following specific functions:

\footnotetext{
${ }^{1}$ PROMETHEE: Preference Ranking Organization Method for Enrichment Evaluations.
} 
Table 1: Generalized Criteria

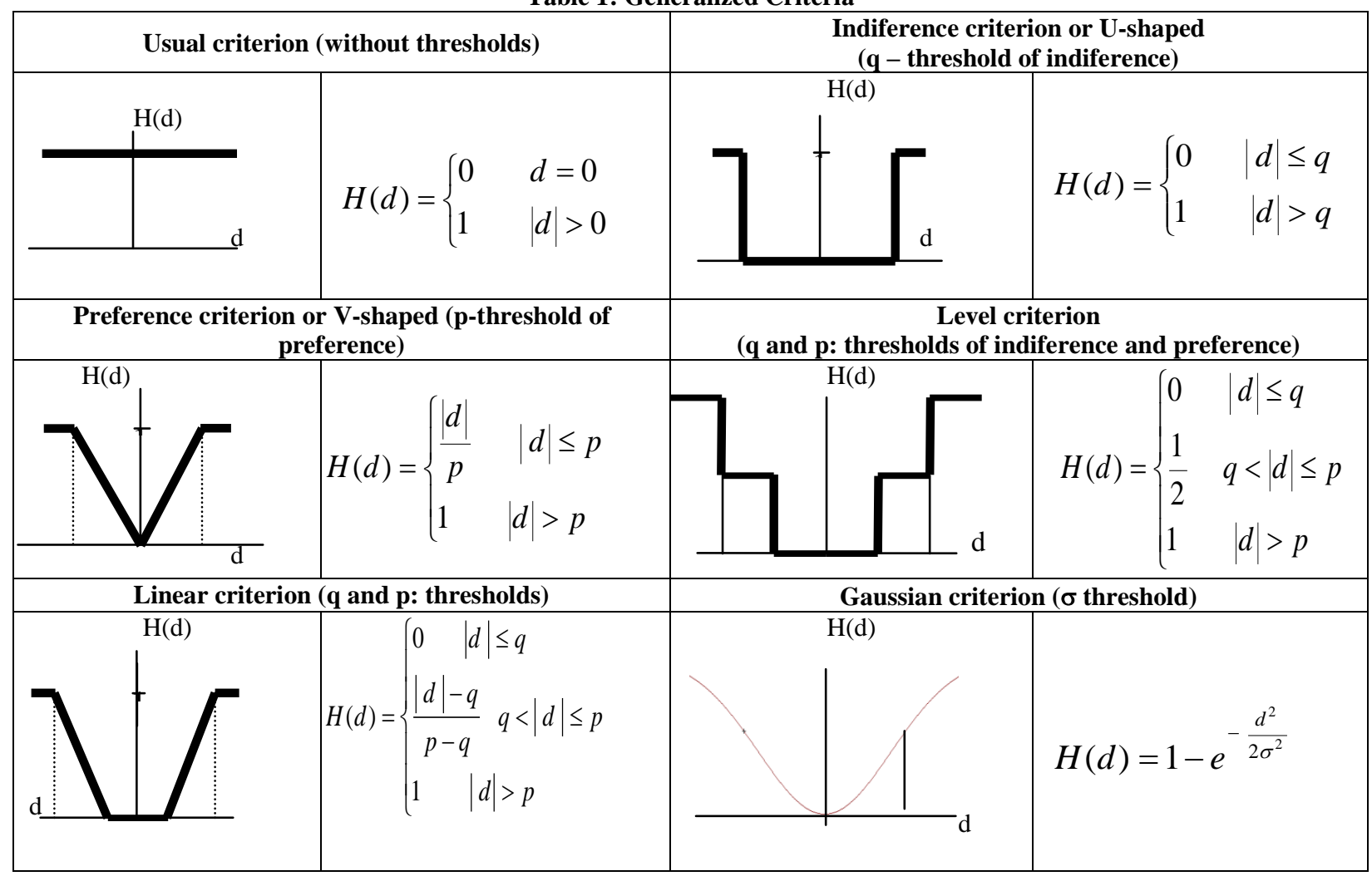

In these functions, $\mathrm{d}$ is the difference between the results of two alternatives for the same criterion, $\mathrm{q}$ is the threshold of indifference and represents the value at which the options cease to be indifferent to a certain criterion, $p$ represents the threshold of preference and its value must always be greater than the threshold value for indifference, $\sigma$ is the threshold used only for Gaussian preference functions and sets the boundary between weak preference and strict preference between two alternatives.

Therefore, this method is based on binary comparisons carried out between each of the alternatives with the rest as part of the decision problem when they are evaluated under different criteria simultaneously, Barba-Romero and Pomerol (1997), Córdoba (2009). Furthermore, the advantage of the discrete multiple criteria decision over other types of learning is, in fact, consider different points of view simultaneously, although they would be contradictory $^{2}$, to be able to set up a ranking (from best to worst) of preferences between World Heritage cities. Moreover, this method is able to compare alternatives evaluated by different criteria which are independent of their measurement units and the priority given to each of them.

Matrix of preference indexes: With all the above information it is possible to calculate the pay-off matrix and, on the other hand, the matrix of preference indexes among alternatives can be extracted from the matrix of decision. This matrix of preference indexes consists of the different indexes of preference of the alternatives calculated for each pair of alternatives. This matrix is square but not symmetric (because the preference index between $a_{i}$ and $a_{j}$ need not be the same as the preference index between $a_{j}$ and $a_{i}$ whose dimension must be seventeen (the number of heritage cities.)

\footnotetext{
${ }^{2}$ These criteria are partially contradictory because, if a decision maker chooses a criterion, an alternative will be chosen as the best, but if you choose another approach you will also choose a different best alternative. That is, the best alternative in each case depends on the criteria chosen by the decision maker.
} 
Each index included in the matrix is calculated as follows: $I\left(a_{i}, a_{j}\right)=\sum_{i} w_{i} H_{i}(d)$

where, $a_{i}, a_{j}$ are two heritage cities; $w_{i}$ represents the normalized weights for each of the criteria; and $H_{i}(d)$ is the corresponding value for each of the preference functions.

Partial ordering and complete ordering of the alternatives: Using the order of preference matrix can be obtained the partial ordering of alternatives or PROMETHEE I. This partial order is obtained from positive flows (or outflows $\phi^{+}$) and negative flows (or inflows $\phi^{-}$). Each of the positive flows shows as an alternative dominates all other alternatives when they are valued by all criteria. Therefore, the higher the value of positive flows the greater the dominance of one alternative over the rest. There is one positive flow for each of the heritage cities and it is calculated from each of the rows of the matrix of preference indexes. On the other hand, the negative flows (as opposed to positive flows) suggest as an alternative is dominated by the other alternatives when they are assessed simultaneously by all criteria considered. As a matter of consequence, an alternative will be better when the smaller its negative flow. Similarly to positive flows, there is only one negative flow for each city and it is obtained from each of the columns of the matrix of preference indexes. Both types of flows can be used simultaneously to establish a ranking of preference among the different alternatives, which provides a range from best to worst in each of the flows. In summary, positive flows will be sorted from highest to lowest while negative flows will be sorted from lowest to highest. Eventually, a city will be better classified when both rankings give the same conclusion.

However, when comparing pair of alternatives considering both types of flows usually it is reached an incomparability, that is, there is a conflict between the ranking obtained with positive and negative flows, and different cities could be preferred under each class of flows.

To solve this problem caused by the existence of incomparabilities, it is possible to use the complete ordering among the alternatives or PROMETHEE II. To obtain the complete ordering the net flows $(\phi)$, defined as the difference between positive and negative flows, are computed as follows

$\phi=\phi^{+}-\phi^{-}$

There is only one net flow for each of the alternatives. These net flows will logically be ranked from highest to lowest using the order of preferences among the different heritage cities according to the criteria considered in this work. Mostly important, the calculation of net flows only is necessary when there are some incomparabilities between the cities. Otherwise the order obtained with the PROMETHEE I will coincide with the order obtained with the PROMETHEE II.

\section{RESULTS}

To carry on the multicriteria decision analysis for the Spanish World Heritage cities we have considered the following variables: the interest attractions, places available to be visited, commercial index, tourism index, restaurants index, an index of economic activity, index of infrastructures, number of hotel beds by categories, percentage of overnights, hotel occupancy rate, average stay, number of consultations made in tourist offices, the whole capacity and budget for tourism. Beginning with the decision matrix created based on the previous variables, the method has reached the following results that contains the evaluations of each of the heritage cities under each of considered criteria.

\subsection{Equal weights}

In this case the function under which each criterion has been evaluated is the usual, since in this form a heritage city is to be preferred to any other if the result of the pay-off matrix for criterion being evaluated is better.

Table 2 shows the calculated values of positive, negative and net flows. Similarly in Figure 1 it is shown a graphical representation of the preference order among the different heritage cities. In this graphics we can appreciate that there is no incomparability between different cities and, also, that the six preferred cities according to 
the criteria considered are: Tarragona, Cordoba, Santiago, Toledo, Salamanca and Segovia, while the least preferred are: Cuenca and Cáceres.

Table 2. positive, negative and net flows with equal weights

\begin{tabular}{|l|c|c|c|c|}
\hline & $\begin{array}{c}\text { Positive Flows } \\
(\phi+)\end{array}$ & $\begin{array}{c}\text { Negatives Flows } \\
(\boldsymbol{\phi})\end{array}$ & $\begin{array}{c}\text { Net Flows } \\
(\boldsymbol{\phi})\end{array}$ & Preference Order \\
\hline Ávila & 0.4118 & 0.5765 & -0.1647 & 8 \\
\hline Cáceres & 0.3353 & 0.6588 & -0.3235 & 11 \\
\hline Córdoba & 0.6353 & 0.3471 & 0.2882 & 2 \\
\hline Cuenca & 0.3765 & 0.6118 & -0.2353 & 10 \\
\hline Ibiza & 0.4353 & 0.5529 & -0.1176 & 9 \\
\hline Mérida & 0.3882 & 0.6000 & -0.2118 & 5 \\
\hline Salamanca & 0.5412 & 0.4529 & 0.0882 & 3 \\
\hline Santiago & 0.5941 & 0.4059 & 0.1882 & 6 \\
\hline Segovia & 0.4529 & 0.5294 & -0.0765 & \\
\hline Tarragona & 0.7176 & 0.2824 & 0.4353 & \\
\hline Toledo & 0.5588 & 0.4294 & 0.1294 & \\
\hline
\end{tabular}

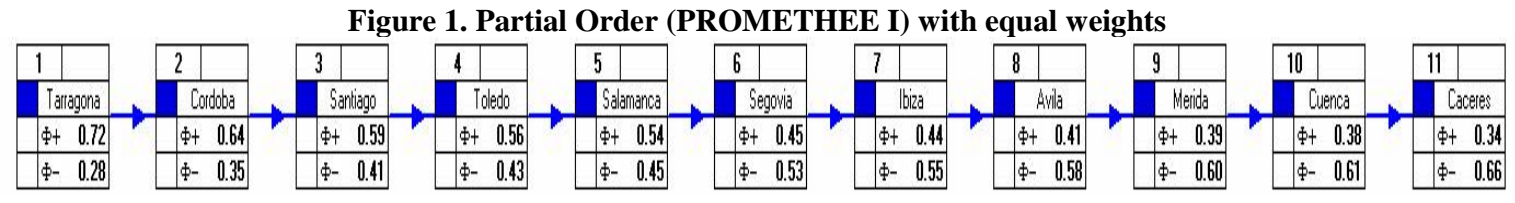

\subsection{Different weights.}

As there are no incomparabilities between the heritage cities, then the complete system, which takes into account only the net flows and it is represented in Figure 2, shows the same order of preference that the partial ordering.

Figure 2. Complete Order (PROMETHEE II) with equal weights.

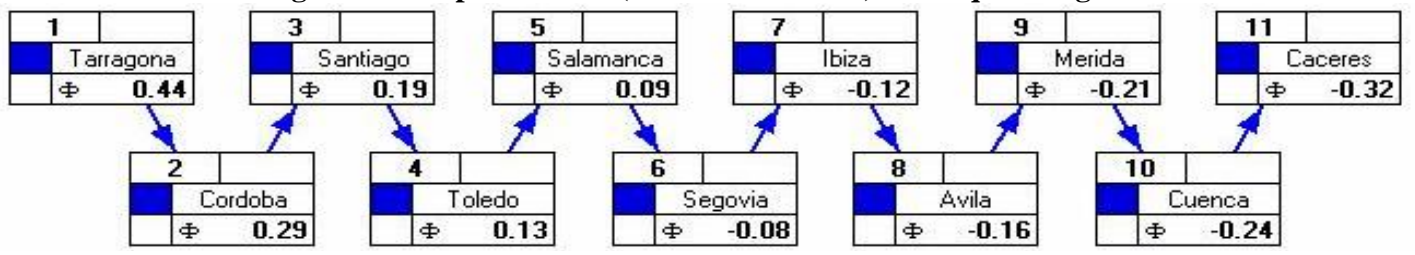

As in the previous case each criterion is assessed under the usual function. Interestingly, we have considered different systems of weights, one of them allows to calculate the weights in an objective manner using the method of entropy, see Table 3. Another considered method overweighs the criteria that are closer to tourism, such as interest attractions, places available to be visited and tourist index as twice the rest of the criteria. However, the results are not shown because they exactly match with those previously shown. This fact shows some evidence of the robustness of our results, since changes in the way of assigning weights to the criteria does not change the ranking obtained. 
Table 3. Weights calculated using the method of entropy

\begin{tabular}{|l|c|l|c|}
\hline \multicolumn{1}{|c|}{ Variable } & Weight & \multicolumn{1}{c|}{ Variable } & Weight \\
\hline Interest attractions & 0.072 & 3 stars Hotels & 0.051 \\
\hline Places ava. to be visited & 0.049 & 2 and 1 stars Hotels & 0.049 \\
\hline Commercial Index & 0.072 & Other accomodations & 0.059 \\
\hline Restaurants Index & 0.068 & Overnights & 0.060 \\
\hline Tourist Index & 0.064 & Hotel Occupancy Rate & 0.039 \\
\hline Econ. Activ. Index & 0.072 & Consults in Tourist Off. & 0.047 \\
\hline Infraestructures Index & 0.052 & Whole Capacity & 0.062 \\
\hline 5 and 4 stars Hotels & 0.041 & Budget & 0.059 \\
\hline
\end{tabular}

If we analyze the values obtained from positive, negative and net flows, provided either in Table 4 or in the graph of partial ordering between the cities shown in Figure 3, it is remarkable that although among the majority of cities there is no type of incomparability, the cities of Toledo and Salamanca are incomparable, because if the positive flow is taken into account Salamanca is preferred because 0.5536 is greater than 0.5560 . On the other hand, if negative flow is considered then Toledo is preferred since 0.4360 is less than 0.4388 . To overcome this incomparability is necessary to use net flows.

Table 4. Positive, negative and net flows with weights computed using the entropy method

\begin{tabular}{|l|c|c|c|c|}
\hline & $\begin{array}{c}\text { Positive Flows } \\
(\boldsymbol{\phi})\end{array}$ & $\begin{array}{c}\text { Negative Flows } \\
(\boldsymbol{\phi})\end{array}$ & $\begin{array}{c}\text { Net Flows } \\
(\boldsymbol{\phi})\end{array}$ & Preference Order \\
\hline Ávila & 0.4336 & 0.5565 & -0.1228 & 7 \\
\hline Cáceres & 0.3323 & 0.6630 & -0.3306 & 11 \\
\hline Córdoba & 0.6567 & 0.3280 & 0.3286 & 2 \\
\hline Cuenca & 0.3591 & 0.6305 & -0.2715 & 10 \\
\hline Ibiza & 0.4279 & 0.5617 & -0.1337 & 8 \\
\hline Mérida & 0.3639 & 0.6257 & -0.2619 & 9 \\
\hline Salamanca & 0.5560 & 0.4388 & 0.1171 & 5 \\
\hline Santiago & 0.6045 & 0.3955 & 0.2090 & 6 \\
\hline Segovia & 0.4472 & 0.5374 & -0.0902 & 1 \\
\hline Tarragona & 0.7192 & 0.2808 & 0.4384 & \\
\hline Toledo & 0.5536 & 0.4360 & 0.1175 & \\
\hline
\end{tabular}

Figure 3. Partial Order (PROMETHEE I) with weights computed using entropy method

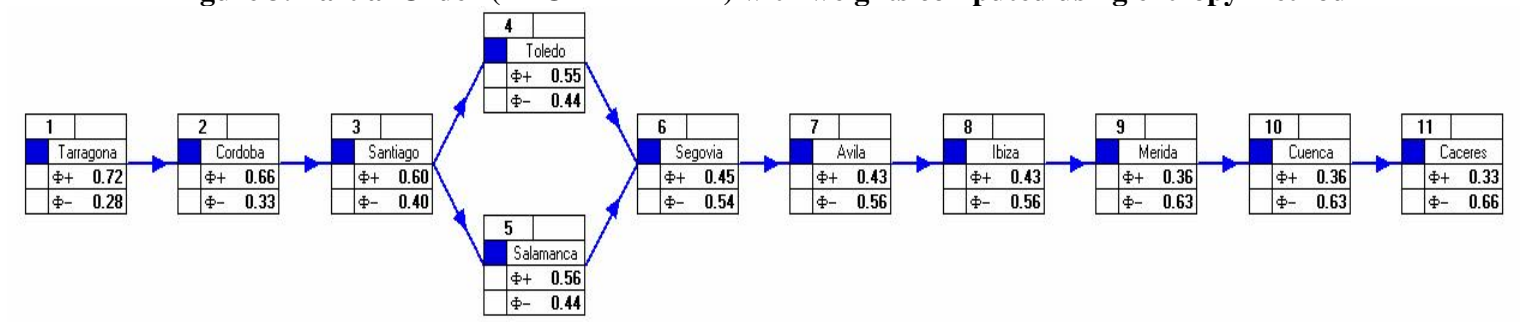

The graphical representation of net flows, given in Figure 4, shows that the incomparability is solved in favor of Toledo city. Finally, the six best ranked cities would be: Tarragona, Córdoba, Santiago, Toledo, Salamanca and Segovia. Also, the least preferred cities remain: Cáceres and Cuenca. This order of preference among the cities demonstrates the robustness of the method used to set up preference orders based on objective criteria. 
Figure 4. Partial Order (PROMETHEE I) with weights computed using entropy method.

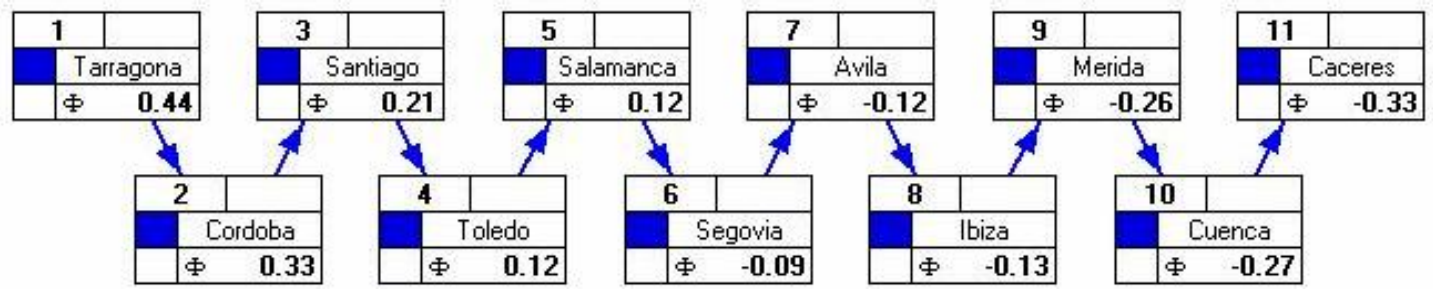

\section{CONCLUSIONS}

This work presents the main facts derived from the application of multi-criteria methodology to rank the World Heritage Cities in Spain. This ranking is based on variables of both supply and demand for tourism as well as considering the inclusion of structural variables such as different levels of urban infrastructures or commercial and economic activity indexes.

In light of the results obtained using different weights, we can conclude that changes in these weights do not alter the final results because it is obtained in both cases identical classifications, except for the cities of Ibiza and Ávila, which alter their positions depending on the scheme of weights.

As a consequence, the multicriteria classification becomes a useful tool for a snapshot of current state of world heritage destinations and should provide guidance to both public and private agents in the development of tourism strategies for the future.

It is obtained a coherent classification consistent with the idea a priori about tourist destinations. In fact, with the exception of Tarragona, located in the first place because its tourism is positively influenced by the sun and beach tourism, cities with less rich heritage, but, especially, those who have worst communications (do not forget the fact that lack of airport or high-speed rail lines, have as a consequence than foreign tourism will be null in practical terms), are located in the last places of the classification.

Although this work is included, as we have previously explained, in a broader research project, in our opinion its main limitation is the static character of the study. Therefore, one of the main lines of future research focuses on analyzing developments in the next years with the addition of new infrastructures and the enhancement of new elements. The aim is to develop dynamic approaches, which allow us to reach new prominent conclusions. The sample selection and collection of additional information are another limitation of this study, and they could cause some biases in our conclusions.

\section{AUTHOR INFORMATION}

Juan-Antonio Mondéjar-Jiménez: $\mathrm{PhD}$ and Degree in Business Administration by University of Castilla-La Mancha. Degree in Advanced Studies in Marketing at the same university. Associate Professor in Marketing at Business Department. Faculty of Social Sciences of Cuenca. University of Castilla-La Mancha (Spain). E-mail: JuanAntonio.Mondejar@uclm.es

Research Interest: Consumer behavior, price perception, e-learning and tourism marketing.

María del Carmen García-Centeno: PhD in Economics by University CEU San Pablo and Degree in Economic and Business Administration by Complutense, Madrid (Spain). Assistant Professor in Econometric at Statistics Department. Faculty of Economics and Business Administration, University CEU San Pablo, Madrid (Spain). Email:garcen@ceu.es.

Research Interest: Stochastic volatility models, regional analysis, educational and tourism. 
Román Mínguez-Salido: PhD in Economics by University CEU San Pablo and Degree in Economic and Business Administration by Complutense, Madrid (Spain). Assistant Professor in Statistics at Statistics Department. Faculty of Social Sciences of Cuenca. University of Castilla-La Mancha (Spain). E-mail: Roman.Minguez@uclm.es.

Research Interest: Stochastic volatility models, regional analysis, educational and tourism.

José Mondéjar-Jiménez: European $\mathrm{PhD}$ in Economics and Degree in Business Administration by University of Castilla-La Mancha. Associate Professor at Statistics Department. Faculty of Social Sciences of Cuenca. University of Castilla-La Mancha (Spain). E-mail: Jose.Mondejar@uclm.es.

Research Interest: disability, regional analysis, educational and tourism.

María Cordente-Rodríguez: Degree in Business Administration by University of Castilla-La Mancha. Lecturer in Marketing at Business Administration Department. Faculty of Social Sciences of Cuenca. University of Castilla-La Mancha (Spain). E-mail: Maria.Cordente@uclm.es

Research Interest: Tourism marketing, consumer behavior and e-learning.

\section{REFERENCES}

1. Almeida, F. (2007): “Análisis de la estructura turística de las ciudades Patrimonio de la Humanidad de España”, Baética: Estudios de arte, geografía e historia, 29, pp. 57-72.

2. Barba-Romero, S., and Pomerol, J. C. (1997): "Decisiones multicriterio. Fundamentos teóricos y utilización práctica". Colección de Economía. Servicio de publicaciones de la Universidad de Alcalá. Madrid.

3. Bedate, A. M.; Sanz, J. A. and Herrero, L. A. (2001): Turismo cultural y patrimonio histórico: Aplicación multivariante al estudio de la demanda, IV Encuentro de Economía Aplicada. Universitat Rovira i Virgili, Reus (Tarragona), 7-9 de junio.

4. Blancas, J., Guerrero, F. M. y Lozano, M. (2009): "La localización espacial en la planificación del turismo rural en Andalucía: un enfoque multicriterio", Revista de estudios regionales, 84, pp. 83-113.

5. Brandis, D.; Martín, F.; Calle, M. de la; Río, M. I. del; Troitiño, M. A.; Gutiérrez, J. and Lobo, P. (1998): "Toledo: problemática e implicaciones urbanas del turismo", Ería: Revista cuatrimestral de geografía, 47, pp. 299-325.

6. Brans, J. P., Mareschal, B. and Vincke, P. H. (1984): "PROMETHEE: a new family of outranking methods in multicriteria analysis", in J.P BRANS (ed.), Operational Research'84, North-Holland, pp. 477-490.

7. Brans, J. P. and Vincke, P. H. (1985): "A preference ranking organization method, the PROMETHEE method" Management Science, 31, pp. 647-656.

8. Cordoba, M. (2009): Fundamentos y Práctica de la Toma de Decisiones. Ed. Dykinson, S.L. Madrid.

9. Daniel, A. y Ramos, F. (2002): "Modelling Inbound International Tourism Demand to Portugal", International Journal of Tourism Research, vol. 4, pp. 193-209.

10. Esteban, A.; Mondéjar, J. A., Mondéjar, J. and Meseguer, M. L. (2008): “Análisis de la inversión de los Programas de Innovación Rural en patrimonio cultural como elemento dinamizador del turismo", Revista de Análisis Turístico, 5, 16-29.

11. Franco, S.; Osorio, M.; Nava, G. y Regil, H. H. (2009): "Evaluación multicriterio de los recursos turísticos. Parque Nacional Nevado de Toluca - México", Estudios y perspectivas en turismo, 18 (2), 208-226.

12. García, M. (2007): "Entidades de planificación y gestión turística a escala local: el caso de las ciudades Patrimonio de la Humanidad de España", Cuadernos de turismo, 20, 79-102.

13. Gómez, M. A., Mondéjar, J.A. and Sevilla, C. (coords.) (2005): Gestión del turismo cultural y de ciudad. Ediciones de la Universidad de Castilla-La Mancha, Cuenca.

14. Goumans, M. and Lygerou, V. (2000): "An extension of the PROMETHEE method for decision making in fuzzy environment: Ranking of alternative energy exploitation projects". European Journal of Operational Research, 123:3, 606-613.

15. Ledesma, F and Navarro, M. (2000): Datos de panel y demanda de turismo: el caso de Tenerife, Documento de trabajo, Universidad de La Laguna.

16. Lim, C. (1997): "An econometric classification and review of international tourism demand models". Tourism economics, vol, 3, pp. 69-81.

17. Molina, A.; Martín-Consuegra, D.; Esteban, A. and Díaz, E. (2007): "Segmentación de la demanda turística: un análisis aplicado a un destino de turismo cultural", Revista de Análisis Turístico, 4, 36-48. 
18. Mondéjar, J.; Mínguez, R.; Meseguer, M. L. and García, M. C. (2010): Equilibrios a largo plazo del turismo: un análisis regional. En Ferrari, G.; Montero, J. M.; Mondéjar, J. and Vargas, M. (coords.): Investigaciones, métodos y análisis del turismo. Septem Ediciones, Oviedo. pp. 333-342.

19. Mondéjar, J., Vargas, M., Mondéjar, J. A. and Lorenzo, C. (2007): “Extracción de señal y predicción en series turísticas". Cuadernos de turismo, 20, pp. 153-170.

20. Mondéjar, J. A. y Gómez, M. A.; (coords.) (2009): Turismo cultural en ciudades Patrimonio de la Humanidad, Ediciones de la Universidad de Castilla-La Mancha, Cuenca.

21. Mondéjar, J. A., Vargas, M., Mondéjar, J. and Gázquez, J. C. (2008): "El turismo en Castilla-La mancha: un análisis de cointegración”. Estudios turísticos, 177, pp. 51-64.

22. Montis, A. De and Nijkamp, P. (2006): "Tourism development and collaborative evaluation: a multicriteria web based planning support system", International Journal of Environmental Technology and Management, 6 (1-2), pp. 40-64.

23. Navía, J. M. (2009): “Ciudades Patrimonio de la Humanidad”. Sociedad Geográfica Española, 32, pp. 114121.

24. Otero, J. (1999): "Las fluctuaciones cíclicas del turismo en Andalucía”. Revista de estudios de economía aplicada, vol. 13, pp. 105-120.

25. Pérez, V.; Camargo, I.; Caballero, R. and González, M. (2008): "Selección multicriterio de nuevos productos turísticos en Pinar del Río, Cuba”. Revista Investigación Operacional, 2 (2), pp. 98-107.

26. Rozman, C.; Potocnik, M.; Pazek, K.; Borec, A.; Majkovic, D. and Bohanec, M. (2009): “A multi-criteria assessment of tourist farm service quality", Tourism Management, 30 (5), pp. 629-637.

27. Sorensen, N. (2003): "Modelling and Monthly Seasonal Forecasting of Hotel Nights in Denmark". En N. Kaergaard [ed.]: Symposium for advendt statistik, pp. 35-50, KVL Press.

28. Troitiño, M. A. (2000): El turismo cultural en las ciudades españolas Patrimonio de la Humanidad. En VV. AA.: Turismo cultural: El patrimonio histórico como fuente de riqueza. Fundación del Patrimonio Histórico de Castilla y León, Valladolid, pp. 11-138

29. Troitiño, M. A., de la Calle, M., García, M. y Troitiño, L. (2009): Observatorio turístico del Grupo de Ciudades Patrimonio de la Humanidad de España. Universidad Complutense, Madrid.

30. Vera, J. F. and Ivars, J.A. (2001): La formación y la investigación turística en España: una visión de síntesis. Papers de turisme, no 29, pp. 6-27.

31. Zou, H. and Yang, Y. (2004): “Combining Time Series Models for Forecasting”, International Journal of Forecasting, vol. 20, nº 1, pp. 69-84. 


\section{NOTES}

